SHS Web of Conferences 24, 01002 (2016)

DOI: $10.1051 /$ shsconf/ 20162401002

C) Owned by the authors, published by EDP Sciences, 2016

\title{
Research on spatial optimization of tourism about Gannan Tibetan scenery tourist village--Taking Binggu as an example
}

\author{
Liang Cheng ${ }^{1,2 *}$, Yanfeng Jiang ${ }^{3 *} \&$ Tong $\mathrm{Li}^{4}$ \\ ${ }^{1}$ School of Architecture and Urban Planning, Huazhong University of Science and Technology, Wuhan, Hubei, \\ China \\ ${ }^{2}$ College of Geography and Environmental Science, Northwest Normal University, Lanzhou, Gansu, China \\ ${ }^{3}$ College of Geographical Science, Guangzhou University, Guangzhou, Guangdong, China \\ ${ }^{4}$ Collage of International Studies, Southwest University, Chongqing, China
}

\begin{abstract}
With the advent of a period of time that people have gone into a leisure era and that tourism has become a prosperous industry, scenery tourist village has become special and much concerned by the tourist and the local villager depending on the tourist attractions. However, there are many problems appeared in the scenic villages tourism development, especially in the organization of tourism space. Take Binggu Village as a specific example, according to the fieldwork investigation and interview, there are some following problems that the landscape space has not been exploited, the culture space has not been developed and the feature space has not been valued. Based on the concept of tourist development, this paper therefore proposes some spatial optimization strategies of tourism to give advices for the sequence and rational tourism development of village, including the ecology "conservation" though expanding the capacity of space, the elements "combination" though extending space and the function "integration" though shifting space.
\end{abstract}

Keywords: $\quad$ scenic tourist village; Gannan Tibetan; tourism space; Binggu Village

\section{BACKGROUND}

With the China's GDP per capita having reached $\$ 6,100$ in 2012 , Chinese people enjoy 115 days of public holidays and the pattern of vacation is transferred from holiday leisure to the usual leisure and paid leave, so society has entered the leisure time. The National Tourism Leisure Outline released in February, 2013, implemented the system of paid leave to promote the tourism and leisure consumption level in urban and rural residents. What's more, health, civilization and the tourism concept of environmental protection have become social consensus, thus tourism has become a new way of life, and health leisure has become the theme of this era. According to the national policy and the social and economic development, many mature tourism scenic spots bring opportunities of development for regional tourism in terms of resources and market due to their great brand attraction.

*Corresponding author: colgate77@163.com
With the development of the tourism industry, a lot of villages within scenic spots have become scenery tourist villages such as folk village of tourism, tourist resort and so on. The tourism model development is produced under the drive of villages-developing its own needs and demands of the leisure development in core scenic area. Therefore, it becomes the new trend of communion development in the scenic tourist villages.

There are innumerable links between scenery tourism villages and scenic areas, such as regional consistency in geographical position, culture, society and economy, and the links provide the cultural soil for the development of rural tourism. Scenery tourism villages which are often regarded as the priority development areas of regional rural tourism experience the course of exploit and development of the scenic area, and it's easy to form a strong sense of tourism service to provide a relatively fine public foundation for tourism development. Meanwhile, the development of rural tourism based on the development of the scenic spots ${ }^{[1]}$ not only meets the subjective needs of rural 
economic development, but also meets the objective needs of tourism areas opening and recreation.

Gannan Tibetan is located in the northeast edge of Qinghai-Tibet Plateau and the junction of Gansu, Qinghai and Sichuan Provinces, and Tibetan is in its west and Han is in its east. Besides, Gannan Tibetan is the frontal zone of economic and cultural exchange between Tibetan and Han. According to the China Tourism Division, Gannan Prefecture is the eastern line tourism area of Gansu tourism that belongs to the sub-district of Northwest Tourism District, which is in the transition zone of Northwest Tourism District, Southwest Tourism District and Qinghai Tibet plateau Tourism District, and it is the intersection of the Silk Road tourism line and Shangri-La tourism line. The characteristics of regional tourism resources, such as diversity, mystery and timing, become one of the important tourism purposes of current folk customs. What's more, there are some scenery tourist villages in famous tourist scenic spots that located in Gannan Tibetan, for example, some 4A scenic areas, Laga village in Laga Mountain scenic spot of Zhouqu, Zecha village in the Zecha stone forest scenic spot of Luqu, Binggu village in Dayugou scenic spot of Zhuoni etc.

\section{OVERVIEW OF SCENERY TOURISM VILLAGE}

\subsection{Concept}

Take the scenic area as backing, scenery tourism village is located within the scenic area and it is one of the important scenic spots in the scenic area with its favorable condition. Besides, the village's development is based on the tourists and unique tourism resources in rural areas. With the help of passengers flow, eminent position and attraction of scenic area, scenery tourism villages develop its own rural tourism, and tourists are the main source of market for the village ${ }^{[2]}$. In the development of villages, more original landscapes of rural villages are remained in scenic tourism village, which makes village space integrate with scenic areas.

\subsection{Characteristics}

\subsubsection{Excellent location and shared landscape}

Scenic tourism village is located in the core circle of scenic area and even in the heart area, in which it has geographically and exclusively natural advantages. Village takes the possibility of region and market for the development of rural tourism with its position. Usually, scenic area has a certain well-known and eminent position. Besides, scenic area enjoys relatively good traffic condition and it is the only road to enter scenery tourism village which provides tourism accessibility for development of village. In the meantime, at the regional level, consistency and integrity of regional culture, tourism resources and tourism lines make it easier to achieve integrated development between scenery tourism villages and scenic areas.

\subsubsection{Excellent market and shared tourist}

Scenery tourism villages are often the important areas possessing tourists' capacity, and commercial service facilities of village can take charge of part shopping service functions and become a naturally supporting tourism service area. And residential living facilities can take charge of part functions of food, accommodation and reception. Relying on market tourism resort, scenery tourism village becomes a natural gathering place or intermediate center, and it gradually has its own market in development, which provides market conditions for rural tourism development.

\subsubsection{Superior resources and complementary development}

"Mutual Assistance" and "Divergence" are of important elements in regional tourism development, and ecological scenery and cultural origin are continuity with tourism villages. However, they have some differences in the direction of scenic developing characteristics in tourism resources and product group which showed as rural scenery and folk customs in villages. Therefore, the development of scenery tourism villages is an organic compensation to the function of tourism product in scenic area and forms the differentiated and complementary development pattern though combining cultural advantages and arrangement development.

\section{BINGGU VILLAGE AND ITS TOURISM SPACE}

\subsection{Profile}

Binggu Village is one of the three natural villages of Wugu administrative village in Muer Town of Zhuoni County, which is the administrative village of Wugu administrative village. Binggu village is located in the scenic areas of Dayugou, and Dayugou's main entrance is in the north of the village about 2,000 meters. And Qibu Temple, Qibulinka Resort, Triangle stone, Thin strip of sky and other core spots are located in the south of the village about 1,500 meters. Villages and scenic areas are independent, and the external traffic is convenient thanks to roads of scenic tourism that go through the village. There are 76 families, namely, 365 people in Binggu Village. It is a traditional village of Juenai Tibetan and, its traditional residential buildings are in good keep which are built closely and densely at the foot of Nanshan. There is a group of the Guest-greeting Pines, which are ancient and rare on the hillside in the north of the village, and the Elephant-Trunk Hill is covered by woodland in the 
south of the village. Dayu River is in the north of village, farmlands are in the river valley between river and village, the village is surrounded by dense vegetation and fresh air, which meet the traditional ideal of "mountain-forest-house-land-river" spatial pattern of layered landscape, and the sequence of the space is a linear progression.

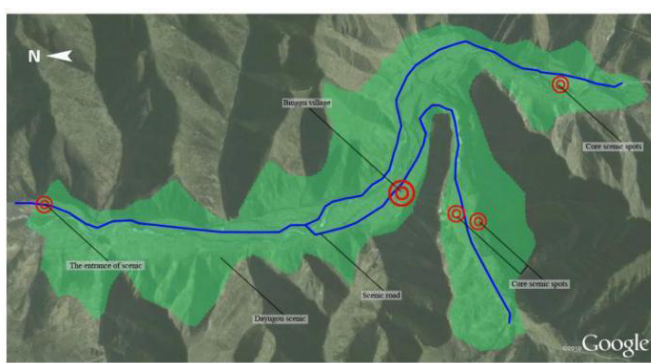

Figure 1. Location signal

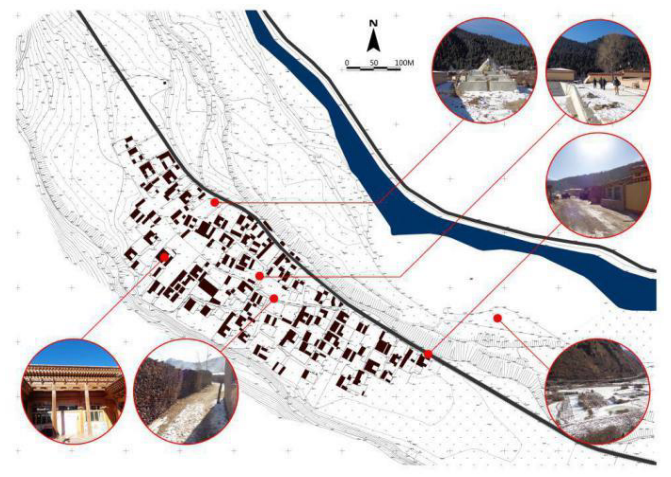

Figure 2. Status signal

\subsection{Tourism space status in Binggu Village}

At present, the rural tourism of Binggu Village has been developed, relying on stable tourist market of Dayugou scenic. Unfortunately, according to the current Binggu situation, we find that there are three major issues that the landscape space has not been used, the cultural space has not been developed and the feature space has not been valued.

Due to the disorganized landscape space, only shops distributed on both sides of transit road that from northern villages to the scenic spot can possess the function of tourism. Tourists only take a temporary stop along the main street of the village and go shopping but few people enter the village and farmland landscape in the north to visit. Therefore, due to the lack of stagnation space, buffer space and guide space for tourism, the space tourism in village is limited.

In addition, the village tourism theme is not clear or even lost; particularly, the organization of internal road has not been combined with traffic, and the absence of theme can guide the organization of the tour line. There are a lot of places in the village with relatively high value of tourism development, such as the White Tower near the north entrance, Mani bourock beside the middle road and the unique Shanzi Housing and so on, which only possess the single function of religion or living at present. The function is not combined with the tourism and travel experience, so the tourism functions of all nodes are insufficient.

\section{TOURISM OPTIMIZATION IN SPACE}

\subsection{Ideas about tourism development}

In recent years, with the example of "Colorful Zhuoni Dayugou", Dayugou has implemented a series of comprehensive projects in scenic areas, such as the demonstrative and pilot project construction of ecological residences reception, the special training of community tourism, the network optimization of internal traffic, the integrated transformation of residential style, the protection and renovation of religious buildings and so on, which made scenic spots have clear themes and distinctive characteristics. The tourist development means the involvement of new space subject like government, enterprises and tourists. For the Binggu Village tourism space, its development should rely on the brand idea of Dayugou Resorts. And development of in-depth experience of country products should be based on the tourist market and self-characteristics. What's more, clearing the tourism position to make use of six major tourism elements including food, life, trip, travel, shopping and entertainment to fully explain rural custom and culture, and focus on improving the open style rural tourism experience and provide the supplementary to the tourism function. Relying on the advantages of Dayugou, elements of rural culture and flexible use of resource can be used to reflect and transform attractive tourist products from the macro-aspects to the micro framework of tourism space.

On the basis of the "mountain -forest-house-landriver" pattern, we need to highlight cultural images of the village, build the central clue of rural tourism development and shape the unique characteristics of tourism product pedigree. Providing a platform for visitors approaching nature and country life by combining the experiencing folk custom of Juenai, sightseeing of traditional village landscape, viewing folk culture heritage of Juenai, enjoying the sight of natural landscape resources of agricultural and other carrier for core products of tourism.

On the basis of tourist theme of Juenai Tibetan folk and art village in Dayugou, we link the village, the edge area and the periphery area of village together. These three different tourism spaces as units extend, expand and shift spaces, respectively. Then we will gradually enlarge its influence through combining the tourism nodes, tourist routes and tourist landscape in 
inorganic ways, and put "Flow Gallery in Dayugou" as the unified marketing slogan, and shape the unique landscape and customs of Binggu, and focus on folk custom holiday, artistic sketch and ecological tourism. Then, through consummating tourism space, tourists can enjoy a picture of ecological landscape, an original atmosphere and the native state of village.

\subsection{Space optimization based on tourism develop- ment}

\subsubsection{Ecology "conservation" though expanding the capacity of space}

The natural landscape around the Binggu Village is diverse and the vast majority of places maintain original natural style, and historical and cultural value of traditional rural settlement is reflected with the whole Shanzi residential building style. The whole village landscape image which is composed of settlement pattern, distribution characteristic and building layout is integral, unique and traditional. Nevertheless, mountain, farmland, river and other natural ecological space around Binggu Village have not been included in the development of village tourism project. Therefore, for the tourism space of Binggu Village, the first thing that we need to do is implementing the optimization strategy for expanding the space capacity to "preserve" ecological environment. We should define such different spaces of ecological tourism as forest conservation of Xiangbishan in the south of the village, farmland landscape conservation in the north and waterfront recreation of Dayu River. We should prevent village ecology from disordered tourism development and construction due to the absence of planning.

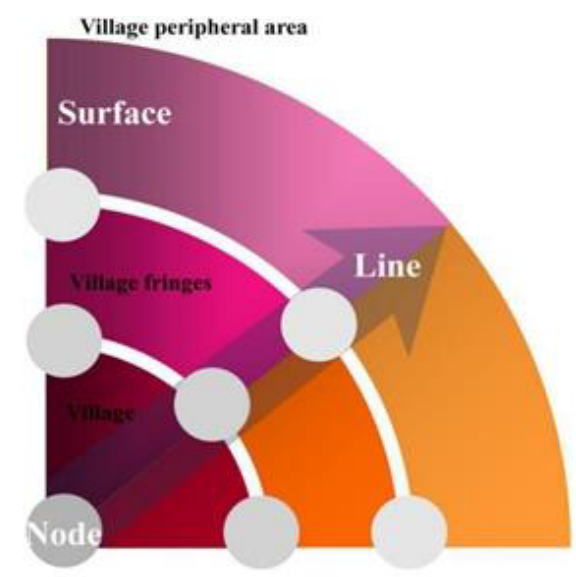

Figure 3. Concept idea

\subsubsection{Elements "combination" though extending space}

It is required to combine every element through the best traveling route ${ }^{[3]}$, so that the different functions of traffic between villages' living and tourists' travel can be well combined. We will use a linear channel which can reflect the local cultural characteristics to connect different nodes of tourist attractions, especially the tourism stream with consciousness needed to be enhanced to rebuild the flow of village space. Tourists can experience tourism, the sightseeing of traditional village landscape, the recreational sightseeing of agricultural landscape and ecologically waterfront leisure recreation by the improved folk and culture. So visitors can not only stay but also spread the transfer along their tourism line which can link every scattering node to the village.

\subsection{3 "Integration" function though spatial shifting}

From the current situation, tourism service facilities in the village are insufficient, especially in the reception center and parking in Binggu Village. On the basis of the existing space and the angle between the people sight and the external interface of the enclosed building, the function space of village tourism can be divided into enclosed space, open space and closed space to form functionalized space. Tourism space includes many different forms of space based on the system planning of village tourism routes and tourism behavior, and characteristic and functional themes of every scenic spot or site as the core. Erik Cohen, a tourism scholar, proposed five modes according to tourism experience in tourism activities ${ }^{[4]}$, which includes Diversionary Mode, Recreational Mode, Existential Mode, Experimental Mode and Experiential Mode. Among these modes, the diversionary mode mainly refers to entertainment and relaxation; the recreational mode is mainly about to rehabilitate health and soothe the mind; the experiential mode is mainly about cultural pilgrimage and religious worship; the experimental mode is mainly about lifestyle, belief and exploration; the experiential mode is mainly about experience the respect of the ceremony. According to the whole village tourism planning and tourism activities, we can identify different travel patterns by scenic spots or sites characteristics and functional theme and we can build a complete scenic tourism village by construction of tourism space and tourism model.

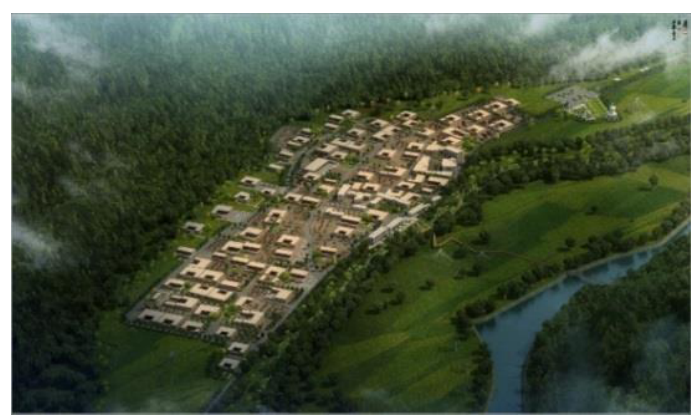

Figure 4. Tourism image 
SSHE 2015

\section{CONCLUSIONS}

The development of scenic tourism village is based on the mature tourist attractions development which causes it to be different from other types of tourist villages, and the natural environment of village is the key factor to appeal visitors. In the meantime, tourism is an industry with rich culture, and any resource related to culture will be valued. The village tourism space is an entity which could reflect the tourism atmosphere and launch the tourism activities. We can reach the purpose of ecological "conservation", elements "combination" and function "integration" through expanding, extending and shifting space, which is the important way to develop such villages in the future.

\section{REFERENCES}

[1] Shi Guoling. 2014. Research on the planning and design of tourism village depends on scenic spot--Taking Shang $\mathrm{Hu}$ village of Bao Shan scenic spot for example. Fujian Architecture \& Construction. 192(6).

[2] Yang Xiaozhong, Ye Shujuan, \& Feng Lixin. 2011. Research on coupling development between scenic-based tourism village and the core scenic area. Yunnan geographic environment research. 23(2).

[3] Bian Yuan. 2009. Study on rural tourism development based on experience economy. A Dissertation Submitted to Shanghai Jiao Tong University for Master's Degree. January.

[4] Erik Cohen, 2007. Contemporary Tourism: Diversity and Change. Chen Liping, Ma Congling \& Wu Ning Trans., Tianjin: Nankai University Press. 